\title{
The protection of minor athletes in sports investigation proceedings
}

\author{
Björn Hessert ${ }^{1,2}$
}

Published online: 30 October 2020

(c) The Author(s) 2020

\begin{abstract}
Sports associations have an interest in the maintenance of a level playing field among all participants. Athletes are therefore bound by the same sporting rules. This also applies to minor athletes who compete at the highest level of their sport. The disciplinary autonomy of sports governing bodies enables them to initiate sports investigations against minor athletes alleged of being in violation of sports regulations, including those pertaining to doping and match manipulation. During the investigations, minor athletes may be obliged to attend sports interrogations or grant full access to diverse of personal information and documentary evidence, including mobile phones, emails, SMS and WhatsApp conversations, and health records. However, the vulnerability of young athletes requires sufficient protection of minors and safeguards in sports investigation proceedings. The aim of this article is to examine the legality of internal sports investigation proceedings against minors in respect to doping and manipulation of sports competition matters. In particular, it analyses whether it is legitimate and reasonable to use investigative measures contained in the regulations of sports governing bodies against minor athletes in the light of the principle of proportionality.
\end{abstract}

Keywords Protection of minors $\cdot$ Sports investigations $\cdot$ Evidence $\cdot$ Doping $\cdot$ Manipulation of sports competitions $\cdot$ GDPR . ECHR

\section{Introduction}

Boris Becker and Maria Sharapova both won their first Wimbledon title at the age of 17. The Finish ski jumper Toni Nieminen was 16 years old when he won two Olympic gold medals at the 1992 Winter Olympic Games in Albertville. The youngest athlete competing at the 2016 Rio Olympic Games was Gaurika Singh, a 13-year-old swimmer from Nepal. These athletes have one thing in common: they all competed at the highest level of their sports at a very young age. In fact, they all participated in adult competitions as minor athletes. The term 'minor' is generally defined as a person under the age of $18 .{ }^{1}$ This definition is also widely accepted in the world of organised sport, cf. Article 19(1) of the FIFA Regulations on the Status and Transfer of Players ('RSTP'). ${ }^{2}$

To be eligible to compete in both junior and adult competitions on a national and international level, minors have to

Björn Hessert

bjoern.hessert@rwi.uzh.ch

1 University of Zurich, Zurich, Switzerland

2 Research Assistant, Teaching Chair for Procedural and Private Law, University of Zurich, Zurich, Switzerland accept the sports regulations of their respective sports association. Once an employment contract or an athlete agreement/ licence agreement (hereinafter referred to as 'entry form') ${ }^{3}$ has been signed, minor athletes are, in principle, bound to the same sporting rules and regulations as their adult competitors. The creation of equal conditions for all participants is one of the core principles in sports. Accordingly, sports organisations aim to ensure and maintain a level playing field and fair competitions among all athletes, including minor athletes. The pursuit of combating doping and the manipulation of sports competitions also require that young athletes are exposed to the same stringent regulations concerning sports investigations.

Within their disciplinary autonomy, guaranteed under national constitutional laws ${ }^{4}$ or Article 11 of the European Convention on Human Rights ('ECHR'), sports governing

\footnotetext{
1 Convention on the Rights of the Child, opened for signature 20 November 1989, 1577 UNTS 3 (entered into force 2 September 1990) ('UNCRC').

2 See also Appendix 1 Definitions 'Minor' of the WADA Code (2021 edition).

3 A minor athlete may also become a direct member of a sports association, cf. Haas and Martens (2011), pp. 66 et seq.

${ }^{4}$ For example Art. 23(1) of the Swiss Constitution or Art. 9(1) of the German Basic Law.
} 
bodies may commence sports investigations against minor athletes who allegedly violated sports regulations. Sports associations may therefore take all necessary measures to gather information with regard to the allegations. Besides the physical participation in interrogations, minors may also have the obligation to grant full access to all kind of personal information and documentary evidence, including mobile phones, emails, SMS and WhatsApp conversations, and health records. The investigation and prosecution of asserted sports violations against minors may not only be in the interests of sports associations themselves. Young and vulnerable athletes must also be protected against greedy coaches, officials, and even parents who put success ahead of the well-being and health of minors. This can be demonstrated by the recent shocking example of child doping in Thailand. ${ }^{5}$ In the German documentary 'Secret Doping - the Lord of the Lifters' broadcast on ARD, the Thai female weightlifter Rattikan Gulnoi, Olympic medallist of the 2012 London Olympic Games, was secretly recorded when she disclosed information about the consumption of doping substances by athletes as young as $13 .{ }^{6}$ She also told the reporters that coaches and officials were either aware of or responsible for this practice. However, in her opinion "those responsible in the federation did not care about her health nor about the health of other athletes."7 The Thai example may not be an isolated case in international sports.

Another cogent example of the vulnerability of young athletes can be found in the world of tennis. Due to the high expenses and low prize money in second-tier tennis competitions, such as ATP Challenger Tour or ITF Future Tour tournaments, young athletes are at higher risk to be tempted to get involved in match manipulation. Organised crime groups and betting syndicates are well aware of the vulnerability of young tennis players, so it is common for such crime groups and syndicates to approach and ask them to throw a match in exchange for money or other benefits. ${ }^{8}$ Young athletes may accept this offer in order to do whatever it takes to make it to the top. However, the vulnerability and inexperience of young athletes must be taken into consideration when examining the legitimacy of sports investigation proceedings

\footnotetext{
${ }^{5}$ Butler N et al. (2020), Gewichtheben: Thailands Olympia-Dritte gibt Einblick in Doping, 5 January 2020, https://www.sportschau.de/ doping/Thailands-Olympiadritte-gibt-Einblicke-in-Doping-100.html (Accessed 6 October 2020).

${ }^{6}$ Ibid.

${ }^{7}$ Nick Butler et al., Gewichtheben: Thailands Olympia-Dritte gibt Einblick in Doping, 5 January 2020, https://www.sportschau.de/ doping/Thailands-Olympiadritte-gibt-Einblicke-in-Doping-100.html (Accessed 6 October 2020).

8 Adam Lewis et al. (2018), Independent Review of Integrity in Tennis - Final Report, 19 December 2018, https://www.tennisintegrity unit.com/storage/app/media/Independent\%20Reviews/Final\%20Rep ort_191218.ppd (Accessed 6 October 2020), paras. 80, 261; see also Opie and Steele (2018), p. 6.
}

against minors. In other words, sports investigations against youth athletes require sufficient protective measures, which must be balanced with the sports associations' interests in investigating and prosecuting alleged sporting misconducts of young athletes. All investigatory powers that the investigating sports association uses against young athletes must therefore be in accordance with the fundamental procedural and substantive rights of minor athletes, protected for example by the ECHR and the Convention on the Rights of the Child ('UNCRC').

Research on the legal situation of young people in the sporting world is not entirely new. However, previous academic work has generally addressed more general - but equally important - issues on the safeguarding of minors in sport, including the protection against sexual and physical abuse and human trafficking. ${ }^{9}$ In these cases, young athletes need to be protected against perpetrators who can put minor athletes' lives at risk. A much less discussed issue is the protection of young athletes who are exposed to sports investigation proceedings. In such proceedings, young athletes are generally suspects rather than victims. In other words, minor athletes are the ones who are accused of having committed a sports rule violation and who therefore should be brought to book. The objective of this work is to divert attention from the wider academic legal analysis on children's rights and sports to a very specific issue that has high relevance in practice: the protection of young athletes in sports investigation proceedings.

Therefore, this article aims to examine the legal situation of minor athletes in internal sports investigation proceedings. More specifically, it addresses the question whether the currently applicable sports regulations as well as mandatory statutory provisions provide sufficient safeguarding mechanisms to effectively protect young athletes in sports investigations of anti-doping rule violations ('ADRV') or manipulation of sports competitions. Protection, for the purpose of this article, means the prevention of physical, mental or legal repercussions of minors. Part 2 of this article gives a brief overview of the sports regulations governing sports investigations applicable to all direct and indirect members of sports governing bodies, including minor and adult athletes. Part 3 analyses the applicability of certain investigative measures against minor athletes on the basis of the principle of proportionality, taking into account the rights of minor athletes as well as the interests of monopolistic sports federations in investigating and prosecuting sports rule violations. It thereby focuses on sports investigations in relation to doping, specifically adverse analytical findings

\footnotetext{
${ }^{9}$ See e.g. Grenfell and Rinehart (2003) pp. 79 et seq; Williams (2008) p. 95; Cornelius and Singh (2011) pp. 294 et seq.; Yilmaz (2018) pp 15 et seq.
} 
('AAF') and non-analytical violations, and manipulation of sports competitions (incl. match-fixing). Part 4 concludes that sports regulations of international sports governing bodies do not provide the necessary protection for vulnerable minors regarding the disclosure of personal documentary evidence. Consequently, new regulations must be introduced within sports organisations to protect the fundamental rights of young athletes during the course of sports investigations.

\section{Internal sports investigation proceedings}

Many sports governing bodies have incorporated specific bodies into their internal structure in order to preventively avert fraudulent behaviour in sport or repressively investigate sports rule violations committed by their members. ${ }^{10}$ In addition to the creation of internal investigative bodies, the constitutionally protected freedom of internal organisation $^{11}$ also entitles sports associations to conduct internal sports investigations into breaches of their sporting rules. In turn, athletes are compelled to accept these sports regulations if they wish to participate in organised sport due to the one-place principle (also Ein-Platz Prinzip) in international sport. ${ }^{12}$ Sportspersons are therefore subject to certain investigatory powers of the investigating sports association. An overview of internal sports investigation procedures in doping and sports competition manipulation matters and the impact on athletes are addressed briefly in the following.

In doping-related matters, investigations are conducted pursuant to Article 5.1.1 of the WADA Code (2021 edition). ${ }^{13}$ At the outset, it is necessary to distinguish between cases with a positive doping test and non-analytical positive. In the former, athletes have the obligation to take part in the doping control process by providing urine or blood samples upon request of the responsible anti-doping organisation ('ADO'), including international sports federation and major event organisations. Athletes who have been included in so-called Registered Testing Pools have an additional duty to provide information on their whereabouts in accordance with Article 5.5 of the WADA Code. ${ }^{14}$ In circumstances where the analysis of the doping sample reveals a prohibited

\footnotetext{
${ }_{10}$ See, eg, the Tennis Integrity Unit ('TIU'), the Athletics Integrity Unit ('AIU') or FIFA's investigatory chamber of the Ethics Committee pursuant to Art. 52(8) of the FIFA Statutes (2019 edition). See also Trunz (2016) pp. 39 et seq. and 113 et seq.

${ }^{11}$ Cf. Article 11 of the ECHR or Article 23 of the Swiss Constitution.

12 Cf. Mutu and Pechstein v. Switzerland, ECtHR, Application No. 40575/10 \& 67474/10, 2 October 2018, para. 113.

13 The new 2021 WADA Code will enter into force on 1 January 2021.
}

substance, the athlete must be informed about the AAF, the alleged ADRV, the right to request an analysis of the B sample and of the possibility to provide any explanation regarding the AAF. ${ }^{15}$ Therefore, the athlete is usually asked to countersign a notification letter and provide the responsible ADO with the required information.

In cases without a positive doping test, sports governing bodies must gather intelligence and evidence in order to satisfy their burden of proof with regard to an ADRV under Article 3.1 of the WADA Code. In this situation, they cannot benefit from the strict liability standard encompassed in Article 2.1 and Article 2.2 of the WADA Code ${ }^{16}$, which means that the mere presence of a prohibited substance found in the athlete's body generally constitutes an ADRV, irrespective of any intention, fault or negligence of the sportsperson concerned. ${ }^{17}$ Consequently, sports governing bodies must resort to other measures to produce cogent evidence to prove an ADRV. For example, sports associations may summon an athlete to appear at an internal sports interrogation. ${ }^{18}$ Based on the regulations to which athletes have submitted themselves, sports governing bodies are further entitled to resort to certain coercive measures. For instance, the regulations of World Athletics ('WA'), the international governing body for the sport of athletics, dictate that upon written demand of the Head of the Athletics Integrity Unit, athletes and other sportspersons be required to disclose all kind of personal information to the Integrity Unit and, ultimately, the sports governing body. Therefore, inter alia, Article 5.10.5 lit. c of the of the WA Anti-Doping Rules (2020 edition) specifies the requestable information which reads - in its pertinent parts - as follows:

provide [...] for inspection, copying and/or downloading any electronic storage device in which the Head of the Integrity Unit reasonable believes relevant information may be stored (such as cloud based servers, computers, hard drives, tapes, disks, mobile tel-

\footnotetext{
${ }^{14}$ Cf. Fédération Nationale des Syndicats Sportifs (FNASS) and Others $v$ France, decision of the ECtHR of 18 January 2018, Application nos. 48151/11 and 77769/13.

15 Art. 7.2 of the WADA Code in conjunction with Article 5.1 of the 2021 International Standard for Results Management.

${ }^{16}$ See Kanagaratnam (2016), pp 107 et seq.

17 Cf. Article 2.1.1 of the WADA Code which reads as follows: "It is the Athletes' personal duty to ensure that no Prohibited Substance enters their bodies. Athletes are responsible for any Prohibited Substance or its Metabolites or Markers found to be present in their Samples. Accordingly, it is not necessary that intent, Fault, Negligent or knowing Use on the Athlete's part be demonstrated in order to establish an anti-doping rule violation under Article 2.1".

${ }^{18}$ Hessert (2020), para. 2.1.
} 
ephones, laptop computers, tablets and other mobile storage devices) $)^{19}$

Similar provisions are contained in the rules, which include provisions for the investigation of cases of manipulation of sports competitions. ${ }^{20}$ Match manipulation can usually only be proven by so-called suspicious betting patterns. ${ }^{21} \mathrm{~A}$ rapid change in the betting market triggers an alert so that the stakeholders involved know that a match or certain parts of a match (e.g. one set of a tennis match) are possibly fixed. However, suspicious betting patterns can only be used as circumstantial evidence, as it remains unclear which individual has acted fraudulently. ${ }^{22}$ Therefore, further investigations are needed to determine which player or umpire was involved in 'the fix'. ${ }^{23}$ This requirement causes difficulties in team sports unless the footage of a game provides clear evidence that a particular player or official had deliberately performed poorly for the sake of manipulating a game. ${ }^{24}$ Therefore, sports investigators turn to investigative measures, such as demand some of the aforementioned personal information, to establish the involvement of athletes in the manipulation of sports competitions.

Sports regulations that entitle sports governing bodies to demand personal information for investigation purposes are obviously in disfavour of the alleged athlete, and thereby engages her or his individual rights as enshrined in national and international law. For instance, the use of personal information may constitutes an infringement of personality rights protected under mandatory national law, e.g. Article 28(1) of the Swiss Civil Code ${ }^{25}$ or a breach of the General Data Protection Regulation ${ }^{26}$ ('GDPR'). Furthermore, in the light of the Mutu and Pechstein judgement of the ECtHR, it can

\footnotetext{
19 Art. 5.10 .5 lit. c of the WA Anti-Doping Rules (2020 edition).

${ }^{20}$ See, e.g. Section F.2.c of the Tennis Anti-Corruption Program (2020) s. F.2.c; Art. 4.4 .5 of the WPBSA Members Rules and Regulations (2017 edition).

${ }^{21}$ See, eg, CAS 2017/A/5173, Joseph Odartei Lamptey v. FIFA, Award of 4 December 2017; CAS 2016/A/4650, Klubi Sportiv Skenderbeu v. UEFA, Award of 21 November 2016; CAS 2014/A/3467, Guillermo Olaso de la Rica v. Tennis Integrity Unit (TIU), Award of 30 September 2014.

22 CAS 2018/A/6075 Igor Labuts v. Football Association of Ireland, Award of 17 July 2020.

23 CAS 2017/A/5173, Joseph Odartei Lamptey v. FIFA, Award of 4 December 2017; CAS 2016/A/4650, Klubi Sportiv Skenderbeu v. UEFA, Award of 21 November 2016.

${ }^{24}$ CAS 2018/A/6075 Igor Labuts v. Football Association of Ireland, Award of 17 July 2020.

${ }^{25}$ Reference to Swiss law is made due to the fact that most sports governing bodies are domiciled in Switzerland.

${ }^{26}$ Regulation (EU) 2016/679 of the European Parliament and of the Council of 26 April 2016 on the protection of natural persons with regard to the processing of personal data and on the free movement of such data, and repealing Directive 95/46/EC (General Data Protection Regulation) [2016] OJ L 119/1.
}

be argued that international human rights law is applicable to monopolistic sports governing bodies - despite their private nature - if athletes have accepted sports regulations on forced basis. ${ }^{27}$ In this case, the athlete's mandatory provision of personal information constitutes an infringement of the athlete's rights to respect her or his private life and correspondence encompassed in Article 8(1) of the ECHR. ${ }^{28}$ However, all of the statutory provisions previously mentioned give sports governing bodies the possibility to justify an infringement of the privacy and personality rights of athletes in order to achieve a legitimate objective pursued, i.e. the protection of the integrity of sport and the maintenance of a level playing field among all participants. By corollary, the interests of both sports governing bodies and athletes must be weighed against each other according to the principle of proportionality.

Accordingly, the investigation and prosecution of sports rule violations in doping and sports competition manipulation matters are legitimate objectives in order to combat all forms of misconduct in sports to promote fair and equal sports competitions. ${ }^{29}$

The test sample collection process is suitable and necessary to achieve the aforementioned aims. In non-analytical violations and manipulation of sports competition investigation proceedings, sports associations must rely on circumstantial evidence. In the absence of direct evidence, other measures must be taken into consideration to establish a breach of sporting rules. Therefore, investigation measures, such as the demand of personal information of athletes, may only be used if less restrictive but equally effective measures are not available. The interrogation of athletes during sports investigations may be less restrictive if the athlete is not compelled to give evidence during her or his interview. ${ }^{30}$ However, if the athlete refers to the privilege against self-incrimination and the right to remain silent, guaranteed under Article 6(1) of the ECHR, an interrogation is not as effective as obtaining personal documentary evidence. In

\footnotetext{
${ }^{27}$ Cf. Mutu and Pechstein v. Switzerland, ECtHR, Application No. 40575/10 \& 67474/10, 2 October 2018, paras. 95, 115; Hessert (2020), para. 3.1; sports governing bodies may also commit themselves to human rights law (cf. Art. 13 of the FIFA Human Rights Policy) or may be entrusted with duties of public authorities (eg in France); see also Fédération Nationale des Syndicats Sportifs (FNASS) and Others $v$ France, decision of the ECtHR of 18 January 2018, Application nos. 48151/11 and 77769/13.

${ }^{28}$ See also the protection of personal data under Art. 8 of the Charter of Fundamental Rights of the European Union, open for signature 18 December 2000, [2000] OJ C 364/1 (entered into force 1 December 2009) ('CFREU').

${ }^{29}$ See e.g. National Federation of Sportspersons' Associations and Unions (FNASS) and others v. France, ECtHR, Application Nos. 48151/11 and 77769/13, 18 January 2018, para. 178 et seq.

${ }^{30}$ See Hessert (2020), para. 3.3.1.2.
} 
this case, there is no less restrictive alternative to the sports governing bodies' demand for personal information and therefore the use of coercive measures to produce cogent evidence in sports investigation proceedings is necessary.

Furthermore, the request of athletes' personal information must be proportionate (in a narrow sense) to justify the infringement of the rights of athletes, including Article $8(1)$ of the ECHR. Doping matters often concern a certain category of personal information, i.e. health data. Personal data relating to the physical and mental conditions of a natural person are considered very sensitive and, in general, may not be processed. ${ }^{31}$ However, the analysis of blood and urine samples serves the purpose of detecting the misuse of prohibited doping substances. The preventive procedure outlined in Article 5 of the WADA Code is thereby not only in the interest of the sports governing bodies but also in the interest of clean athletes. Both have an interest in combating doping in sport in the light of the principle of fairness. On balance, the interests of sports governing bodies prevail in this regard. ${ }^{32}$

Nevertheless, in proceedings involving non-analytical violations and match manipulation incidents, health data are not suitable for establishing a violation of sports regulations, except in longitudinal profiles. ${ }^{33}$ Therefore, sports governing bodies may gather other personal information, for example personal data stored on clouds and personal electronic devices. The interest of sports associations outweigh the rights of athletes to respect one's private life and correspondence insofar as the obtained information has a direct link to the investigated matter. In turn, a violation of mentioned rights cannot be justified if the provided information has a purely private nature, e.g. family pictures or private text messages with the athlete's spouse. In this case, the processing of personal information cannot be justified as it does not serve the purpose of investigating a specific asserted sports rule violation and, thus, constitutes a violation of the athlete's rights under Article 8(1) of the ECHR. In this case, any purely private information must be deleted immediately and may not be processed by the respective sports governing body.

While young athletes, as direct or indirect members, are subject to the same sports investigation regime of sports authorities, certain aspects might be taken into consideration when investigating minor athletes. More fundamentally, it may be necessary to derogate from certain sports regulations

\footnotetext{
$\overline{31}$ Cf. Article 9(1) of the GDPR.

32 See also National Federation of Sportspersons' Associations and Unions (FNASS) and others v. France, ECtHR, Application Nos. 48151/11 and 77769/13, 18 January 2018.

${ }^{33}$ For example the so-called Athlete Biological Passport ('ABP').
}

in order to act in the minors' best interests, bearing in mind the vulnerability and inexperience of young sportspersons.

\section{Sports investigations against alleged minor athletes}

\subsection{Minors as addressees of sports investigation regulations}

While there seems to be a common understanding that minor athletes are bound by the regulations of sports organisations in the same way as their adult counterparts, the legal examination of a contractual relationship between sports associations and youth athletes appears to be more complicated. Youth athletes are only subject to sports regulations, including regulations on sports investigations, if they have submitted to them. In order to do so, minor athletes generally have to sign a membership contract, employment contract or entry forms.

This seems problematic for two reasons. First, athletes under the age of 18 usually lack legal capacity. In this case, the sports association or the competent judicial body needs to examine whether the minor athlete has legal capacity to enter into a contract with the sports association or the athlete's employer. Second, if an athlete lacks legal capacity, the question arises as to who may act on behalf of the minor as her or his legal representative. The obvious answer to that would be the athlete's parents. However, in the sporting sector, coaches, officials or other third parties may also act on behalf of athletes, especially when the athlete participates in international sports competitions without being accompanied by her or his parents.

The question whether minor athlete have legal capacity to sign an entry form or other legal documents, such as the AAF notification letter, might be determined based on either the national law of the country where the minor athlete is domiciled or the law of the country in which the parties have entered into the contract. By default, the competent adjudicatory authority will have to determine the legal capacity of minors based on the conflict of laws provision. For instance, Article 35 of the Swiss Federal Statute on Private International Law ('PILA') provides that the capacity of minors is subject to the law of the country where the minor is domiciled (lex domicilii). ${ }^{34}$ In addition to the domicile or habitual residence of a minor, the law of the country "most closest connected" 35 to the contract, i.e. the proper law, may apply. Considering the best interest of minors, the competent body

\footnotetext{
${ }^{34}$ See also Article 7 of the Introductory Act to the German Civil Code ('EGBGB').

35 Briggs (2013), para. 20.146.
} 
may still conclude that the lex domicilii of the minor athlete is the proper law to decide on her or his legal capacity.

In the international sports environment, especially before the Court of Arbitration for Sport ('CAS'), Swiss law is the predominant national law applicable to sports disputes. ${ }^{36}$ If Swiss law applies, Article 35 of the PILA is the decisive provision on the legal capacity of minors. Accordingly, the legal capacity will depend on the lex domicilii of the youth athlete. For example, a minor athlete from the UK becomes contractually capable at the age of 18 . Prior to the obtainment of legal capacity, Section 2 of the Children Act 1989 governs the parental responsibility for minor athletes, providing in paragraph 1 as follows: "Where a child's father and mother were married to each other at the time of his birth, they shall have parental responsibility for the child." Similar regulations can be found in other national laws, which may differ with regard to the requirement for representation by both parents or sufficient single representation. ${ }^{37}$ Accordingly, minor athletes are generally not allowed to enter into a direct or indirect membership with sports governing bodies. In addition, a lot of (indirect) membership contracts between sports governing bodies and youth athletes may therefore be null and void. If one accepts this conclusion, the presumption of tacitly accepted rules and regulations of international sports federations based solely on participation in sports competitions ${ }^{38}$ does not apply to youth athletes without legal capacity. Minor athletes will only be subject to sports regulations if their guardian have signed a membership agreement/entry form on behalf of the minor with either the national sports governing body or international sports governing body. Otherwise, the sports organisations lack disciplinary jurisdiction over a minor athlete as she or he is not bound by the respective sports rules and regulations, including anti-doping rules. Consequently and in respect of the WADA Code, Signatories to the Code must establish procedures to ensure that the legal representatives of minors have agreed that the minor is bound by anti-doping rules and that the person acting on behalf of the youth athlete has accepted the respective anti-doping rules as a condition of the minor athlete's participation in a sports competition. ${ }^{39}$ This legal obstacle may not be bypassed by the constitutional

\footnotetext{
${ }^{36}$ Cf. Articles R45, R58 of the Code of Sports-related Arbitration ('CAS Code'). In arbitration proceedings before the CAS, Swiss law often applies according to the applicable regulations, e.g. Article 57(2) of the FIFA Statutes (2019 edition), or, subsidiarily, due to the fact that most international federations are domiciled in Switzerland, cf. in detail Haas (2015) pp. 7-17.

37 See, eg, Sections 1626, 1629 of the German Civil Code; Section 18 of the South African Children's Act.

38 See in detail Teetzel and Mazzucco (2014), p. 923; Sullivan (2016), p. 70; see also Freeburn (2018), pp. 113-114.

39 Cf. 'Introduction' of the 2021 WADA Code.
}

protected autonomy of sport. The mandatory statutory provisions on legal capacity must therefore be respected by sports associations. Accordingly, sports organisations must ensure that the parents of the minor, or any other person who has custody over her or him, may represent the young athlete when she or he submits to the regulations of sports governing bodies. As a consequence, minor athletes cannot grant effective power of agency to third parties. Only the athlete's guardian has the legal capacity to consent to the legal representation of minor athletes by coaches, sports officials or any other person acting as the athlete's support personnel. For example, members of a National Olympic Committee ('NOC'), including the chef de mission or the deputy chef de mission, may act as representatives of the minor athlete during the Olympic Games. The youth athlete's guardian, however, must approve this power of representation. ${ }^{40}$ This finding must be borne in mind when discussing sports investigations against young athletes in the following.

\subsection{Sports investigations concerning AAF violations}

\subsubsection{Sample collection session}

The concept of parental responsibility for minor athletes is reflected in the sample collection process in doping matters. Annex B to the 2021 WADA International Standard for Testing and Investigations ('ISTI') contains specific requirements for the sample collection involving athletes under the age of 18. Articles B.3.1 of Annex B to the ISTI therefore provides as follows:

The Testing Authority has responsibility for ensuring, when possible, that the DCO has any information necessary to conduct a Sample Collection Session with an Athlete who is a Minor. This includes confirming wherever necessary that the necessary parental consent for Testing any participating Athlete who is a minor. (emphasis added)

In turn, the Testing Authority would be in breach of the ISTI when testing a minor athlete without the consent of the athlete's legal guardian.

Interestingly, it can be observed that the ISTI distinguishes between the general consent for testing a minor athlete and the sample collection process itself. The former expressly requires the parental consent whereas any adult can support the youth athlete during the sample collection

\footnotetext{
${ }_{40} \mathrm{CF}$. Articles 14.2, 14.3 of the IOC Anti-Doping Rules (2019 edition) ('IOC ADR').
} 
process. ${ }^{41}$ Therefore, Article B.4 of Annex B to the ISTI reads - in its pertinent parts - as follows:

Athletes who are Minors should be notified in the presence of an Athlete representative (who is not a Minor) in addition to the DCO/Chaperone and may choose to be accompanied by a representative throughout the entire Sample Collection Session. Even if the Minor declines a representative, the Sample Collection Authority or DCO, as applicable, shall consider whether another third party ought to be presented during notification of and/or collection of the Samples from the Athlete [...] The Testing Authority or Sample Collection Authority (as applicable) shall consider the appropriate course of action when no Athlete representative (who is not a Minor) is present at the Testing of an Athlete who is a Minor [...] and shall accommodate the Minor in locating a representative if requested to do so by the Minor.. ${ }^{42}$

This distinction seems to be appropriate for practical reasons in the light of the specificity of sport. The provision of doping samples cannot be qualified as a declaration of will of a minor. It is rather a natural act without the intention of achieving legal success (geschäftsähnliche Handlung). Even though such acts may still require legal representation of minor athletes ${ }^{43}$, the particularities of sport necessitates that the regulations of sports associations deviate from the stringent regime of contract law as long as the protection of minors is still ensured, bearing in mind that parents have, in principal, consented to sports regulations on behalf of the minor athlete. Therefore, it deems appropriate that persons other than their parents support young athletes during the sample collection session due to the effectiveness of the anti-doping system. As mentioned before, parents are not always present during the competitions of their children. It is common that minor athletes are chaperoned by other support personnel. Otherwise, no samples could be collected from minor athletes, which would result in loopholes in favour of young athletes and to the detriment of the anti-doping system. The required safeguarding measures for the protection of minors are fulfilled since young athletes can be represented throughout the collection session and can select

\footnotetext{
${ }^{41}$ See, eg, Article 7.4.6 of the ISTI (2015 edition) which reads as follows: "At the conclusion of the Sample Collection Session the Athlete and DCO shall sign appropriate documentation to indicate their satisfaction that the documentation accurately reflects the details of the Athlete's Sample Collection Session, including any concerns expressed by the Athlete. The Athlete's representative (if any) and the Athlete both sign the documentation if the Athlete is a Minor [...]." (emphasis added). See also Teetzel and Mazzucco (2014) p. 921.

42 Article B.4.4, 4.8 of Annex B to the ISTI.

43 Säcker et al. (2018), para. 40 on s. 133.
}

the representative themselves. Furthermore, the regulations provide that, at least, the Doping Control Officer ('DOC') must be present if a minor declines to be represented. The refusal of any representation shall be documented. ${ }^{44}$ The particularities of the sample collection process for young athletes must be implemented by the IOC, the international sports federations and other Signatories to the WADA Code in order to be code-compliant. By and large, minors are sufficiently protected over the course of sample collection which is, ultimately, based on the consent of the athlete's guardian.

\subsubsection{Results management}

A positive doping test of a minor athlete triggers the same result management applicable to any other AAF, cf. Articles 7.2 of the WADA Code in conjunction with the recently approved International Standard for Results Management ('ISRM'). ${ }^{45}$ Specific regulations concerning the results management of minors are contained neither in the WADA Code nor in the International Standard for Results Management. Therefore, it must be asked whether certain safeguarding measures are necessary for the purpose of the protection of minors in the context of the results management in relation to an AAF.

In case of an AAF without a so-called Therapeutic Use Exemption ('TUE') or a departure from the ISTI or the International Standard for Laboratories ('ISL') that may have caused the AAF, the organisation responsible for results management has the obligation to immediately notify an athlete of the AAF and give her or him the opportunity to open the athlete's B Sample pursuant to Article 5.1.2 of the ISRM. In the latter, any athlete, regardless if adult or minor athlete, can decide to be represented during the opening of the B Sample. Opening the B Sample without giving the athlete an opportunity to be present renders the A and B Sample inadmissible for evidential purposes in the light of due process. ${ }^{46}$ Nevertheless, athletes also have the right to waive the right to request the analysis of the B Sample and consequently accept the AAF.

In order to confirm the notification, decide on the opening of the B Sample as well as on the acceptance of the consequences as provided in the applicable anti-doping regulations, athletes must complete a form, e.g. the AAF

\footnotetext{
44 Article B.4.6 of Annex B to the ISTI.

45 The new International Standard for Results Management will enter into force on 1 January 2021.

46 See, eg, CAS 2010/A/2161, Wen Tong v. International Judo Federation (IJF), Award of 23 February 2011, para. 16; CAS 2016/A/4828, Carlos Ivan Oyarzun Guinez v. Union Cycliste Internationale (UCI) \& UCI Anti-Doping Tribunal \& Pan American Sports Organization (PASO) \& Chilian National Olympic Committee (CNOC), Award of 31 May 2017 para. 122.
} 
notification letter or the Acceptance of Consequences form. Thereby, both the decision, i.e. the right to open the B Sample, and the acceptance of related consequences, constitute a natural act, which requires legal representation of minor athletes due to their lack of legal capacity. Consequently, the minor athlete's guardian, usually her or his parents, must sign any form on behalf of the athlete, including the AAF notification letter. It is therefore required that not only the athlete, but also the guardian should be appropriately informed of the AAF of a minor for safeguarding reasons. ${ }^{47}$ A specific regulation in this respect is not included in the ISRM. Therefore, Article 5.3.7 lit. b) of the ISTI, which provides that " $a$ third party is required to be notified [...] where the Athlete is a Minor", should be applied by analogy to fill this lacuna.

However, this requirement seems difficult, bearing in mind that parents are not always present during training sessions and competitions. Furthermore, in certain circumstances, it can be difficult for anti-doping organisations, international sports federations, or event organisers to allocate the legal representative of minor athletes. In order to avoid such difficulties during the Period of the Olympic Games, Article 14.3 of the IOC ADR provides as follows:

During the Period of the Olympic Games [...] and for the purpose of the application of these Rules, the Athlete and other Person shall be deemed to be validly represented by the NOC, acting through the person mentioned in Article 14.2.

Accordingly, members of their NOC legally represent minor athletes during the Olympic Games and therefore the NOC can accept consequences and waive rights of youth athletes on their behalf. ${ }^{48}$ However, in the light of the above, the minor athlete has no capacity to authorise the members of the NOC to legally represent her or him at the Olympic Games. Only the guardian of an athlete is entitled to grant power of representation in favour of the NOC. ${ }^{49}$ This requirement is met if the athlete's guardian has already signed the entry form and thus granted the power of representation by reference or if the power of representation has been conferred by signing a separate declaration of representation. Otherwise, a power of representation does not exist. Consequently, all declarations of will by sports organisations on behalf of minor athletes must, in principle, be based on

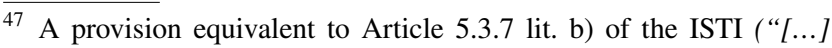
third party to be notified [...] where the Athlete is a Minor") is however not contained in Article 5 of the ISRM.

48 CAS 2016/A/4777, Izzat Artykov v. International Olympic Committee (IOC), Award of 21 April 2017, para. 148.

49 The same applies to the representation of minor athletes by other sports organisations.
}

the consent of the athlete's guardian for safeguarding the interests of minor athletes.

\subsection{Sports investigations in connection with non-analytical positive and sports competition manipulation}

The detection of non-analytical violations or sports competition manipulation allegedly committed by minor athletes appears to be more complicated in the absence of direct evidence comparable to AAFs. Sports regulations of international sports associations usually contain no specific provisions dealing with the investigation of minors. For example, the ISTI does not contain any provision on the collection of documentary evidence of minors. Instead, minors are subject to the same rules and regulation on sports investigations as their adult counterparts. The lack of knowledge and inexperience of athletes seems to be a factor of consideration only in the determination of the appropriate sanction as a mitigating element. ${ }^{50}$ However, international sports federations have implemented aforementioned investigative measure, which may have a serious impact on the fundamental rights of minor athletes, taking into account that athletes generally have no choice whether or not to accept such measures. The following section therefore discusses whether mandatory statutory provisions limit the autonomy of sports governing bodies insofar as they could be obligated to adopt new provisions to protect the rights of minor athletes.

\subsubsection{Sports interrogation}

The interrogation of minors in sports proceedings must basically follow the same principles as for adult athletes, with the exception that the guardian must always be wellinformed about each individual part of the proceedings. Furthermore, the rights of a person under investigation to a fair trial enshrined in Article 6(1) of the ECHR are applicable if an athlete was forced to accept the regulations of a monopolistic sports association. ${ }^{51}$ Accordingly, a minor athlete cannot be compelled to provide any information in her or his possession and therefore may invoke the privilege against self-incrimination or the right to remain silent in sports investigation proceedings. ${ }^{52}$ However, a young athlete

\footnotetext{
${ }^{50}$ See, eg, CAS 2015/A/4273, World Anti-Doping Agency (WADA) v. Sri Lanka Anti-Doping Agency (SLADA) \& Don Dinuda Dilshani Alexander, Award of 29 April 2016, para. 42; see also CAS 2008/A/1490, World Anti-Doping Agency (WADA) v. United States Anti-Doping Agency (USADA) \& Eric Thompson, Award of 25 June 2008, paras. 22 et seq.

51 Mutu and Pechstein v. Switzerland, ECtHR, Application No. 40575/10 \& 67474/10, 2 October 2018, para. 115.

${ }^{52}$ See Hessert (2020), para. 3.3.1.
} 
under investigation does not have the right to abstain from being questioned and must therefore attend the interrogation upon notification by the sports association. The rather passive obligation to be physically present for questioning is not a serious encroachment of the athletes' fundamental rights. ${ }^{53}$ In order to protect the rights of minors, young athletes have the right to be legally represented during interrogations. The athlete's guardian should also have the right to attend the interrogation. In addition, sports officials may have the obligation to provide the sports association with criminal records before they are allowed to question minors in order to prevent any form of abuse. ${ }^{54}$

\subsubsection{Collection and disclosure of personal information}

According to the regulations of sports governing bodies, athletes may be served a notice of disclosure in which the person in charge of sports investigations is entitled to demand all kind of personal information. In other words, minor athletes may also be obliged to disclose documentary evidence contained on their mobile phones, personal computers, including emails, and so forth. The provided information may subsequently be exchanged with other sports organisations or state law enforcement agencies due to the criminalisation of sports-specific conduct, such as doping ${ }^{55}$ or match manipulation. ${ }^{56}$ The collection and disclosure of intelligence might be justified in order to achieve fair competitions and a sporting level playing field, as previously discussed. However, the protection of minors may be one factor that could influence the outcome of the balancing process between the interests of sports associations and the protection of minors' fundamental rights to private life and personal data in favour of the latter.

As a starting point for this discussion, it is required to look at certain mandatory statutory provisions that could possibly restrict the sports federations' freedom to deal with all internal matters on their own without external interference. The first framework, which could possibly limit the autonomy of sport in respect to minor's private life, is the UNCRC. Article 16 of the UNCRC provides that "unlawful interference with [child's] privacy, family, home or correspondence" is prohibited. The wording of Article 16(1) of the UNCRC corresponds to the wording of Article 8(1)

\footnotetext{
53 See mutatis mutandis Jalloh v. Germany, ECtHR, Application No. 54810/00, 11 July 2006, para. 70.

${ }^{54}$ Cf. Regulation 2.1 of the Football Association's Safeguarding Regulations.

55 E.g. Section 4 of the German Anti-Doping Act; Section 22a of the Austrian Anti-Doping Act.

${ }^{56}$ E.g. Section 265c-e of the German Criminal Code; Article 25a of the Swiss Sports Promotion Act, see also Hessert (2019), 268-278.
}

of the $\mathrm{ECHR}^{57}$. Both Conventions therefore prohibit any 'unlawful interference' with minor's right to respect one's private life and correspondence, including the personality rights of minors. However, a definition of 'unlawful interference' does not exist in mentioned Conventions. National and international law must therefore fill this lacuna.

Within the European Union, the GDPR sets forth prerequisites for the processing of minors' personal information. Based on Article 8(1) of the GDPR in conjunction with Article 6(1)(a) of the GDPR, it is necessary to distinguish between minor athletes above and below the age of 16. Minor athletes above the age of 16 are legally entitled to consent on their own to the processing of their personal information. In turn, athletes below this age limit lack legal capacity and thus require the consent of their legal representatives, e.g. parental representation. Any processing of personal information without the necessary consent constitutes, in principal, an unlawful interference of the personality rights of minor athletes.

In this case, it is not only required that the athlete's legal representative informally consents to the collection of personal information during sports investigation proceedings, including information contained on personal electronic devices. It is further required that their legal representative consents to the disclosure of information to law enforcement agencies or other sports bodies, cf. e.g. Article 14.1.2 of the WADA Code in conjunction with Article 14.6 of the WADA Code. Whether informed consent to the transmission of information is given depends on the wording of the written consent provided by the legal representative. The term "collection" does not suffice to establish consent to the exchange of information, as this term refers to a specific category of the overall term "processing" ${ }^{58}$ It is therefore recommended to use the term "processing" or, at least, "disclosure" of information to meet the requirements set out in the GDPR and be therefore permitted to disclose information to other entities if consent is given.

The consent-based approach to both the collection and disclosure of personal information would create loopholes in the fight against fraudulent behaviour in sport. Parents and other legal representatives, who are complicity involved in an ADRV or the fix of a match, could deliberately deny the provision of an informed consent. In this case, sports organisations would be prevented from collecting personal information of minor athletes during sports investigation proceedings. For example, minor athletes would no longer

\footnotetext{
57 Article 16(1) of the UNCRC reads as follows: "No child shall be subjected to arbitrary or unlawful interference with his or her privacy, family, home or correspondence, nor to unlawful attacks on his or her honour and reputation."

58 GDPR, art, 4(2).
} 
be subject to provisions on the disclosure of personal documentary evidence on request of the investigating sports organisation. The inapplicability of sports regulations on internal investigations would however be a fatal blow for the detection of sports rule violations. It would further open the floodgates for cheating minor athletes and their legal representatives. Moreover, the hands of sports associations would be tied, because mandatory national and transnational data protection laws would always trump provisions contained in their sports rule and regulations due to its private nature.

Fortunately - from the sports associations' point of view - the importance of consent prior to the access and collection of personal information has only limited relevance in sports investigations under the GDPR. Article 6(1)(e) of the GDPR permits the processing of information in the interest of the public. The GDRP itself recognises the reduction and/ or elimination of doping in sport for the protection of public health as a public interest within the meaning of Article 6(1) (e) of the GDPR.${ }^{59}$ In this regard, the collection of doping samples as well as the disclosure of test results between ADOs serves, inter alia, the purpose to protect the health of athletes and is therefore permitted under Article 6(1)(e) of the GDPR. ${ }^{60}$ However, the disclosure of intelligence to law enforcement in both doping and match-fixing matters are not primarily aiming at protecting public health. It mainly serves the purpose of assisting the criminal investigations carried out by police and prosecutors. Nevertheless, the fight against doping and the manipulation of sports competitions is in the interest of the public in contracting states to the UNESCO International Convention against Doping in Sport ${ }^{61}$ and the Council of Europe Convention on the Manipulation of Sports Competition ${ }^{62}$ and must therefore be qualified as a public interest pursuant to Article 6(1)(e) of the GDPR. ${ }^{63}$

In addition, Article 6(1)(f) of the GDPR gives sports associations the right to collect and exchange personal information for investigation purposes based on the grounds of their legitimate interest in investigating and prosecuting sports rule violations for repressive and preventive reasons. It is undoubtedly further in the interests of honest athletes

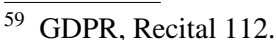

60 Van der Sloot et al. (2014), p. 86.

61 International Convention against Doping in Sport, open for signature 19 October 2005, 2419 UNTS 201 (entered into force 1 February 2007);

62 Convention on the Manipulation of Sports Competition, opened for signature 18 September 2014, CETS No 215 (entered into force Sept.1, 2019).

${ }^{63}$ See also e.g. Meca-Medina and Majcen v. Commission of the European Communities (C-519/04 P) [2006] ECR I-7006, I-7018, para. 43; National Federation of Sportspersons' Associations and Unions (FNASS) and others v. France, ECtHR, Application Nos. 48151/11 and 77769/13, 18 January 2018, para. 181.
}

that all participants play the game in conformity with the rules.

However, the wording in both Article 6(1)(e) and (f) of the GDPR requires that the processing of information has to be necessary which ultimately leads to the application of the principle of proportionality, taking into account the protection of personal data, age, lack of knowledge, inexperience and vulnerability of young athletes. ${ }^{64}$ As already pointed out above, on the one hand, the processing of personal information of athletes for investigation purposes may be justified if the gathered intelligence has a direct link to the sporting matter under investigation. On the other hand, the imbalance between monopolistic sports associations and vulnerable minor athletes appears to be larger than in the relationship between sports federations and adult athletes. Young athletes are forced to accept rules and regulations of monopolistic sports governing bodies and, in addition, do not have the necessary experience, maturity, and capability to understand the legal dimension of their actions. The protection and safeguarding of minors is the most important aspect in this respect. Therefore, Recitals 74, 75 of the GDPR foster the responsibility of sports associations, as data collectors within the meaning Article 4(7) of the GDPR ${ }^{65}$, to take appropriate and effective measures to protect minors. Such measures seem all the more important when minor athletes are compelled to disclose personal information which they have never (forcibly) consented to on their own.

In consideration of the competing interests, it appears to be proportionate for minor athletes to provide information for internal sports investigation proceedings, provided that such information is used solely for the purpose of investigating and prosecuting sports rule violations. In this case, the information collected remains within the sports organisation to protect the integrity of sport. Nevertheless, the processing of information for the objectives of fairness and equality in sport seems to be excessive when personal information of minor athletes is shared with third parties. Accordingly and under consideration of Recitals 74, 75 of the GDPR, international sports federations have the obligation to implement safeguarding measures in order to avoid any misuse of exchange of minors' personal data with third parties (e.g. the transmission of personal information with state law enforcement agencies), taking into account the forced nature of the provision of documentary evidence, such as mobile phone data or emails. The current absence of specific safeguarding

\footnotetext{
${ }^{64}$ GDPR, art. 6(1)(f) stresses the importance of the protection of children ("in particular where the data subject is a child").

${ }^{65}$ See Viret M (2019), How Data Protection Crystallises Key Legal Challenges in Anti-Doping, 7 May 2019, https://www.asser.nl/Sport sLaw/Blog/post/how-data-protection-crystallises-key-legal-challenges -in-anti-doping-by-marjolaine-viret (Accessed 6 October 2020).
} 
prerequisites for the protection of inexperienced and vulnerable athletes is incompatible with the GDPR and, thus, an unlawful interference of the minor athletes' privacy and personality rights. Consequently, minors cannot be forced to provide personal data for investigation purposes as long as sports federations have not implemented protection instruments to ensure that the information remains within the sphere of the investigating sports association for the purpose of internal matters. The rights of minor athletes to respect their private life and correspondence under Article 16(1) of the UNCRC, Article 8(1) of the ECHR must prevail in this context. An infringement of said rights cannot be justified in order to investigate and prosecute sports rule violations. In the light of the above, in sports investigations of non-analytical violations and matters of sports competition manipulation, sports governing bodies are not entitled to resort to coercive measures to obtain personal information of minor athletes in order to protect inexperienced and vulnerable young athletes against serious violations of their privacy and personality rights. In this case, all sports rule violations allegedly committed by minor athletes must be proven otherwise.

\section{Conclusion}

The number of youth athletes competing in professional sports is considerably high. Fair competition among all participants requires that all athletes be bound by the same rules and regulations. Sports governing bodies as well as athletes benefit from a level playing field in both athletic and financial terms. Therefore, minor athletes must also submit to the same sporting regulations in order to ensure fair and comparable competitions. Sports governing bodies have the power to implement regulations for both adult and minor athletes based on their regulatory autonomy. Consequently, sports regulations on the commencement of sports investigation into breaches of sporting rules allegedly committed by athletes also apply to young sportspersons. The investigation of young athletes may not only serve the purpose of protecting the integrity of sport, but it can also protect the health, financial, or legal situation of athletes. For instance, the detection of child doping within a national federation may lead to investigations against that federations in question, as seen in the case of the Thai female weightlifter Rattikan Gulnoi $^{66}$, and ideally prevents such practices in the future.

\footnotetext{
$\overline{66}$ Butler N, Mebus J (2020), Nach ARD-Doku: Dopingverfahren gegen Thailands Star-Heberin Gulnoi, 2 October 2020, https://www. sportschau.de/doping/Nach-ARD-Doku-Dopingverfahren-gegen -Thailands-Star-Heberin-Gulnoi-100.html (Accessed 5 October 2020).
}

However, the autonomy of monopolistic sports federations is limited insofar as minor athletes must be protected in their best interest. The lack of knowledge, compatibility of understanding, inexperience, and vulnerability of young sportspersons must also be taken into consideration in sports investigations and not only as a mitigating factor in determining the appropriate sporting sanction. Furthermore, it should be borne in mind that minor athletes generally lack legal capacity and thus require representation by their legal guardians. In order to protect the interests of minor athletes during sports investigations, his or her legal guardian should be always informed about each step from the very outset of the investigation proceedings.

The assessment conducted in this article has shown that there are safeguards for minor athletes with respect to AAF doping violations. Sporting rules and mandatory statutory provisions therefore limit the autonomy of sports governing bodies in favour of young athletes. However, a sufficient protection of minors does not exist in sports investigations concerning non-analytical violations and the manipulation of sports competitions. The demand of sports governing bodies to provide and disclose all kinds of personal data cannot be justified by the aimed sporting objective of a level playing field. Taking into account the dominant position of monopolistic sports federations, the compelled acceptance of sports regulations and the inexperience of youth athletes, governing bodies must be prevented from requesting personal information from minors, especially when such information may possibly be shared with state law enforcement agencies. In the light of the principle of proportionality, minor athletes must be protected against such coercive measures in sports investigations. Sports governing bodies need to ensure to act in the best interest of minors. Under the present legal situation, minor athletes are only adequately protected if sports organisations are prevented from forcibly collecting personal information of minors, taking into account the associated risk of abuse of power arising from cooperation between sports organisations and law enforcement in combating fraudulent behaviour in sport. As long as sports organisations do not take the required measures to protect vulnerable minor athletes in sports investigation proceedings, they must establish any sports rule violation of the alleged minor on the grounds of other reliable means of proof.

Funding Open access funding provided by University of Zurich.

Open Access This article is licensed under a Creative Commons Attribution 4.0 International License, which permits use, sharing, adaptation, distribution and reproduction in any medium or format, as long as you give appropriate credit to the original author(s) and the source, provide a link to the Creative Commons licence, and indicate if changes were made. The images or other third party material in this article are included in the article's Creative Commons licence, unless indicated 
otherwise in a credit line to the material. If material is not included in the article's Creative Commons licence and your intended use is not permitted by statutory regulation or exceeds the permitted use, you will need to obtain permission directly from the copyright holder. To view a copy of this licence, visit http://creativecommons.org/licenses/by/4.0/.

\section{References}

Adam L et al (2018) Independent review of integrity in tennis - final report, 19 December 2018, https://www.tennisintegrityunit. $\mathrm{com} /$ storage/app/media/Independent\%20Reviews/Final\%20Rep ort_191218.ppd, paras. 80, 261. Accessed 14 January 2020

Briggs A (2013) Private international law, 3rd edn. Oxford University Press, Oxford

Cornelius S, Singh P (2011) Protection of young athletes. In: Nafziger J, Ross S (eds) Handbook on international sports law. Edward Elgar, Cheltenham, pp 294-307

Freeburn L (2018) Regulating international sport - power, authority and legitimacy. Brill Nijhoff, Leiden

Grenfell C, Rinehart R (2003) Skating on thin ice-human rights in youth figure skating. International Review for the Sociology of Sport 38/1 (2003) 79-97

Haas U (2015) Applicable law in football-related disputes- the relationship between the CAS Code, the FIFA statutes and the agreement of the parties on the application of national law. CAS Bull 2:7-17

Haas U, Martens D-R (2011) Sportrecht - eine Einführung in die Praxis, 1st edn. Schulthess Juristische Medien AG Schriftenreihe Causa Sport, Zürich

Hessert B (2020) Cooperation and reporting obligations in sports investigations. Int Sports Law J 20, 145-156(2020). https://doi.org/https ://doi.org/10.1007/s40318-020-00169-5.

Hessert B (2019) Straftatbestände gegen Wettkampfmanipulationen ein gelungener Start. Causa Sport 19:268-278

Kanagaratnam S (2016) Issues in the gathering and use of non-analytical evidence to prove anti-doping rule violations. In: Haas U, Healey D (eds) Doping in sport and the law. Hart, Oxford, pp 107-125

Marjolaine V (2019) How data protection crystallises key legal challenges in anti-doping, 7 May 2019. https://www.asser.nl/Sport sLaw/Blog/post/how-data-protection-crystallises-key-legal-chall enges-in-anti-doping-by-marjolaine-viret. Accessed 6 October 2020

Nick B, Jörg M (2020) Nach ARD-Doku: Dopingverfahren gegen Thailands Star-Heberin Gulnoi, 2 October 2020. https://www.sport schau.de/doping/Nach-ARD-Doku-Dopingverfahren-gegen-Thail ands-Star-Heberin-Gulnoi-100.html. Accessed 5 October 2020

Nick B et al (2020) Gewichtheben: Thailands Olympia-Dritte gibt Einblick in Doping, 5 January 2020. https://www.sportschau.de/dopin g/Thailands-Olympiadritte-gibt-Einblicke-in-Doping-100.html. Accessed 6 October 2020

Opie H, Steele S (2018) Comparing approaches to match-fixing in sport - revisiting perceptions and definitions. In: Opie H, Steele S (eds) Match-fixing in sport - comparative studies from Australia, Japan, Korea and Beyond, 1st edn. Routledge, New York, pp 3-17

Säcker F, Rixecker R, Oetker H, Limperg B (2018) Münchner Kommentar zum Bürgerlichen Gesetzbuch, 8th edn. C.H, Beck, Munich

Sullivan A (2016) The world anti-doping code and contract law. In: Haas U, Healey D (eds) Doping in sport and the law. Hart, Oxford, pp 61-80

Trunz M (2016) Ein globaler Lösungsansatz zur Bekämpfung der Spiel- und Wettspielmanipulation im Sport. Dike Verlag AG, Zurich/St, Gallen

Teetzel S, Mazzucco M (2014) Minor problems: the recognition of young athletes in the development of international anti-doping policies. Int J History Sport 31(8):914-933. https://doi. org/10.1080/09523367.2013.854774

Van der Sloot B, Paun M, Leenes R, McNally P, Ypma P (2017) Antidoping \& data protection - an evaluation of the anti-doping laws and practices in the eu member states in the light of the general data protection regulation. Publication Office of the European Union, Luxembourg

Williams B (2008) The fate of third party ownership of professional footballers' rights: is a complete prohibition necessary. Texas Rev Entertain Sports Law 10(1):79-102

Yilmaz S (2018) Protection of minors: lessons about the FIFA RSTP from the recent Spanish cases at the Court of Arbitration for Sport. Int Sports Law J 18:15-28. https://doi.org/10.1007/s4031 8-018-0126-y

Publisher's Note Springer Nature remains neutral with regard to jurisdictional claims in published maps and institutional affiliations. 